\title{
ON CHRONOSTRATIGRAPHIC CALIBRATION USING BRYOZOA: SUGGESTIONS FROM TWO PALEOGENE CASE STUDIES
}

\author{
Salvador REGUANT \\ Dept. Estratigrafia i Paleontologia. Fac. de Geologia. Universitat de Barcelona. \\ 08028 Barcelona, Spain. reguant@natura.geo.ub.es
}

\begin{abstract}
Reguant, S. 2000. On chronostratigraphic calibration using Bryozoa: suggestions from two Paleogene case studies. [Consideraciones acerca del uso de los briozoos para la calibración cronoestratigráfica: sugerencias a partir del análisis de dos casos del Paleógeno]. Revista Española de Paleontología, 15(1), 71-75. ISSN 0213-6937.
\end{abstract}

\begin{abstract}
The bryozoan species present in each Paleocene and Eocene chronostratigraphic unit of the Atlantic and Gulf Coastal Plains in North America, and the Paris Basin in France are analysed. The comparison between species exclusive to each unit considered (EX), non-exclusive species, but appearing for the first (FA) or last time (LA), species existing before and after the unit considered (BA), and, finally, the total number of species present (T), shows the chronostratigraphic discriminating value of this fauna within the Paleogene. The same analysis was previously applied to bryozoan Paleocene and Eocene families and genera, according to the information available. It is also interesting to note the significant renewal of bryozoan fauna in both basins during the Middle Eocene.
\end{abstract}

Keywords: Bryozoa, chronostratigraphic calibration, Paleogene, southeastern North America, Paris Basin.

\section{RESUMEN}

Se expone un análisis de la fauna de briozoos encontrada en los sedimentos paleocénicos y eocénicos de dos áreas, SE de Estados Unidos y cuenca de París. El cómputo de formas exclusivas (EX), formas no exclusivas que aparecen por primera vez (FA), o por última vez (LA), formas presentes antes y después (BA) y total de especies presentes $(\mathrm{T})$ en cada unidad cronoestratigráfica considerada permiten ver el valor cronoestratigráfico discriminante de este tipo de fauna en el Paleógeno. Previamente se indican los resultados de la aplicación del mismo tipo de análisis al total de familias y géneros conocidos en los sedimentos del Paleoceno y el Eoceno. Por otra parte, es interesante observar la renovación importante de la fauna de briozoos en ambas cuencas durante el Eoceno medio.

Palabras clave: Briozoos, calibración cronoestratigráfica, Paleógeno, sudeste de Estados Unidos de América, Cuenca de París.

\section{INTRODUCTION AND PURPOSE}

An analysis of the contents of contributions at the eleven International Bryozoology Association (IBA) Conferences held until now (Reguant, 1999) shows that only 3 contributions are devoted to the use of Bryozoa in oil research. All these contributions were presented at the first IBA Conference supported by AGIP, a leading Italian oil company (Annoscia, 1968a). The first contribution by Annoscia (1968b) is a report on paleontological and stratigraphical research carried out by the AGIP paleontological laboratory, pointing out the applied use of bryozoans. Secondly, Boardman (1968) asserts that Paleozoic Bryozoa are useful in providing detailed stratigraphic control. Finally, Gautier (1968) discusses why bryozoans as microfossils may be useful in oil research, and quotes a prophecy, as Gautier himself calls it, of the late Sir Sidney Harmer in 1930. Harmer wrote: "it is evident that many of the geological formations are well characterized by their Polyzoa. It is probable that with increasing knowledge, this phylum will become more important than at present as a means of correlating the age of strata, and that the assistance of students of the group will be more sought in connection with economic problems in Geology".

Even today, some 70 years later, this prophecy has yet to be fulfilled. However, some studies on the stratigraphic use of fossil post-Paleozoic bryozoans have been published. One can cite, discussing different aspects of this topic, Peniguel (1959), Buge (1972), Voigt (1985), 


\begin{tabular}{|l|c|c|c|c|c|}
\hline & EX & FA & LA & BA & T \\
\hline CYCLOSTOMATA & 0 & 0 & 4 & 16 & 20 \\
\hline CHEILOST. ANASCA & 0 & 7 & 1 & 13 & 21 \\
\hline CHEIL. CRIBRIMORPHA & 0 & 0 & 1 & 2 & 3 \\
\hline CHEIL. ASCOPHORA & 0 & 7 & 1 & 6 & 14 \\
\hline
\end{tabular}

Table 1. Bryozoan families present in the Paleocene.

and myself (Reguant 1993, 1995). Trying to verify the value of the bryozoan fauna as a chronostratigraphic calibrating tool, I revised the information available on Paleocene and Eocene bryozoan faunas from two basins in which the stratigraphy is well known, the Paris Basin, and the Atlantic and Gulf Coastal Plains. However, first I present data on bryozoan families and genera known from the Paleocene and Eocene.

\section{BRYOZOAN FAMILIES AND GENERA FROM THE PALEOCENE AND THE EOCENE}

I have compiled five kinds of data from information available. Firstly, the number of taxa which are exclusive to the chronostratigraphic unit considered (EX). Secondly, the number of non-exclusive taxa making first appearance in each unit (FA). Thirdly, the number of non-exclusive taxa making last appearance in each unit (LA). Fourthly, the number of taxa existing in the chronostratigraphic unit considered, and also before and after this unit (BA). Finally the total number of taxa present in each chronostratigraphic unit $(\mathrm{T})$.

Tables 1 to 4 show these data on bryozoan families and genera through the information supplied, respectively, for families by Taylor (1993), and for genera by Bassler (1953) with some amendments according to Sepkoski (1982).

Comparing Tables 1 and 2 it is evident that the larger number of Cheilostomatida Ascophora families first appearing in Eocene times, in contrast with the small number appearing in the Paleocene, indicates a significant renewal of this group of bryozoan fauna. The new Eocene families of Ascophora represent $81 \%$ of the total Eocene families.

\begin{tabular}{|l|c|c|c|c|c|}
\hline & EX & FA & LA & BA & T \\
\hline CYCLOSTOMATA & 0 & 1 & 0 & 16 & 17 \\
\hline CHEILOST. ANASCA & 0 & 7 & 0 & 13 & 20 \\
\hline CHEIL. CRIBRIMORPHA & 0 & 0 & 0 & 2 & 2 \\
\hline CHEIL. ASCOPHORA & 0 & 24 & 0 & 6 & 31 \\
\hline
\end{tabular}

Table 2. Bryozoan families present in the Eocene.

\begin{tabular}{|l|c|c|c|c|c|}
\hline & EX & FA & LA & BA & T \\
\hline CYCLOSTOMATA & 1 & 3 & 1 & 34 & 39 \\
\hline CHEILOST. ANASCA & 1 & 8 & 1 & 42 & 52 \\
\hline CHEIL. CRIBRIMORPHA & 1 & 0 & 2 & 10 & 13 \\
\hline CHEIL. ASCOPHORA & 2 & 22 & 0 & 15 & 39 \\
\hline
\end{tabular}

Table 3. Bryozoan genera present in the Paleocene.

The number of Paleocene last appearances of cribrimorphs is also significant. Cribrimorphs constitute the smallest group of post-Paleozoic bryozoans, including only 11 families, 8 of which are exclusively Cretaceous. The extinction of 1 family during the Paleocene emphasizes the affinities between Paleocene and Cretaceous faunas and results in the existence of only 2 families of cribrimorphs, both extant. However, as no bryozoan families are exclusive to the Paleocene, and only 1 to the Eocene, it seems that the identification of families found within stratigraphic sections is not a good indicator of the age of strata.

It is particularly apparent that there is a greater number of genera in Eocene beds than in Paleocene in all groups, particularly in Ascophora. Also there are more first appearances than last appearances in both Paleocene and Eocene times. Ascophora show an important renewal in genera, even in the Paleocene where $62 \%$ of genera are new. In Eocene times there are 99 new genera which represent $72 \%$ of all genera extant. Also the number of genera exclusive to the Eocene is high, especially in Cyclostomata and Ascophora. These data show that the fossil remains of these two groups have a potential discriminating value in the stratigraphic attribution of the marine strata containing them.

\section{BRYOZOAN FAUNAS IN TWO SPECIFIC BASINS}

Two case studies are discussed below concerning the bryozoan faunas present within two basins or areas with well-defined Paleogene stratigraphies: the Atlantic and Gulf Coastal Plains of North America, and the Paris Basin in France.

\begin{tabular}{|l|c|c|c|c|c|}
\hline & EX & FA & LA & BA & T \\
\hline CYCLOSTOMATA & 12 & 9 & 2 & 35 & 58 \\
\hline CHEILOST. ANASCA & 6 & 21 & 1 & 49 & 77 \\
\hline CHEIL. CRIBRIMORPHA & 2 & 5 & 5 & 7 & 19 \\
\hline CHEIL. ASCOPHORA & 26 & 73 & 3 & 35 & 137 \\
\hline
\end{tabular}

Table 4. Bryozoan genera present in the Eocene. 


\begin{tabular}{|l|c|c|c|c|c|}
\hline & EX & FA & LA & BA & T \\
\hline CYCLOSTOMATA & 26 & 2 & 0 & 0 & 28 \\
\hline CHEILOST. ANASCA & 16 & 1 & 0 & 0 & 17 \\
\hline CHEIL. CRIBRIMORPHA & 8 & 0 & 0 & 0 & 8 \\
\hline CHEIL. ASCOPHORA & 12 & 0 & 0 & 0 & 12 \\
\hline
\end{tabular}

Table 5. Midwayan bryozoan species.

\section{The Atlantic and Gulf Coastal Plains}

Canu and Bassler (1920) described more than 550 bryozoan species from the Paleocene and Eocene of these regions of North America. This excludes the Upper Marlboro beds because, on the one hand, it seems that their chronostratigraphic age is uncertain and, on the other hand, these beds contain only 22 identified species.

The American Paleocene-Eocene series comprise, according to Mancini and Tew (1991): Midwayan (Lower Paleocene and lowermost part of Upper Paleocene); Wilcoxian (uppermost part of Upper Paleocene and lowermost part of Lower Eocene); Claibornian (uppermost part of Lower Eocene, and Middle Eocene, except the uppermost part), and Jacksonian (uppermost part of Middle Eocene and Upper Eocene).

Tables 5 to 8 show the species distribution according the methods established above for families and genera.

The first observation that can be made is the richness in species in Jacksonian time, and, to a lesser extent, in the Midwayan, in extreme contrast with the low number of species found in both the Wilcoxian and Claibornian. Most Midwayan and Jacksonian are exclusive to those series. All in Wilcoxian. Obviously, bryozoan species are good tools to identify these three series in marine successions, at least in these basins and adjacent areas. Much work is required to extend this conclusion to areas away from southeastern North America.

The data considered indicates that bryozoan diversity drops to a minimum between the end of the Paleocene and terminal Middle Eocene. A faunal revision is needed to ascertain whether the small number of bryozoan species reflects a broader historical trend in the phylum, or correlates with a small number of available specimens, due to peculiar unfavourable sedimentary or taphonomic conditions.

\begin{tabular}{|l|c|c|c|c|c|}
\hline & EX & FA & LA & BA & T \\
\hline CYCLOSTOMATA & 2 & 0 & 0 & 0 & 2 \\
\hline CHEILOST. ANASCA & 4 & 0 & 0 & 0 & 4 \\
\hline CHEIL. CRIBRIMORPHA & 0 & 0 & 0 & 0 & 0 \\
\hline CHEIL. ASCOPHORA & 5 & 0 & 0 & 0 & 5 \\
\hline
\end{tabular}

Table 6. Wilcoxian bryozoan species.

\begin{tabular}{|l|c|c|c|c|c|}
\hline & EX & FA & LA & BA & T \\
\hline CYCLOSTOMATA & 1 & 3 & 0 & 1 & 5 \\
\hline CHEILOST. ANASCA & 4 & 6 & 0 & 1 & 11 \\
\hline CHEIL. CRIBRIMORPHA & 0 & 0 & 0 & 0 & 0 \\
\hline CHEIL. ASCOPHORA & 5 & 10 & 0 & 0 & 15 \\
\hline
\end{tabular}

Table 7. Claibornian bryozoan species.

What is positively demonstrated is the renewal of fauna in the uppermost part of the Middle Eocene. The number of species is very high for both Cyclostomata and Cheilostomata. Only Cribrimorpha are represented by fewer species. But, as noted above, the Cribrimorpha are depauperate in the Cenozoic. In these basins, as the tables show, cribrimorphs disappeared during the Paleocene, but in the Jacksonian suffered a notable renewal with 20 species, 16 of them exclusive to this stage.

\section{Paris Basin}

Buge (1964) compiled data on the Paleogene bryozoan fauna of the Paris Basin. More recently, Braga and Bignot (1986) have added 7 Paleocene bryozoan species to this fauna.

Tables 9 to 12 show the species distribution within the groups established.

The Paleocene and Lower Eocene bryozoan faunas are poor, but the Paleocene fauna contains only exclusive species; therefore, when present, it identifies Paleocene beds. The Middle Eocene, mainly the Lutetian, contains the richest fauna, with exclusive species constituting about $80 \%$ of the total. As is known, the Upper Eocene is not well represented in marine facies in the Paris Basin. On the other hand it is possible to conclude, according to the information available, that the bryozoan fauna of the Middle Eocene and also Upper Eocene beds from basins to the South (SW France, Pyrenees and North Italy) agree in abundance and variety with those of the Paris Basin. Similarly, as in southeastern North America, the Cribrimorpha disappear and reappear, in this case in the Ypresian and Lutetian respectively.

The number of species is smaller than in southeastern North America, but a renewal of fauna is clearly apparent in the Lutetian. In Bartonian times the remaining species

\begin{tabular}{|l|c|c|c|c|c|}
\hline & EX & FA & LA & BA & T \\
\hline CYCLOSTOMATA & 87 & 19 & 2 & 3 & 111 \\
\hline CHEILOST. ANASCA & 105 & 11 & 6 & 1 & 123 \\
\hline CHEIL. CRIBRIMORPHA & 16 & 4 & 0 & 0 & 20 \\
\hline CHEIL. ASCOPHORA & 155 & 12 & 10 & 0 & 177 \\
\hline
\end{tabular}

Table 8. Jacksonian bryozoan species. 


\begin{tabular}{|l|c|c|c|c|c|}
\hline & EX & FA & LA & BA & T \\
\hline CYCLOSTOMATA & 4 & 0 & 0 & 0 & 4 \\
\hline CHEILOST. ANASCA & 7 & 0 & 0 & 0 & 7 \\
\hline CHEIL. CRIBRIMORPHA & 1 & 0 & 0 & 0 & 1 \\
\hline CHEIL. ASCOPHORA & 2 & 0 & 0 & 0 & 2 \\
\hline
\end{tabular}

Table 9. Dano-Montian-Thanetian bryozoan species.

of Cyclostomata disappear, and the number of species diminishes in the other three groups, but Cheilostomatida Anasca and Ascophora are represented by more than 10 species, many of them exclusive to this stage. Therefore, bryozoans are useful for chronostratigraphic calibration, both in the Paleocene and in the Middle Eocene.

To avoid confusion it is useful to remember that the Bartonian was formerly placed in the Upper Eocene. Modern studies and recently the International Subcommission on Paleogene Stratigraphy, have concluded that the Bartonian beds of the Paris Basin underlie the Priabonian, accepted as the sole stage of the Upper Eocene (Cavelier and Pomerol, 1976, Jenkins and Luterbacher, 1992).

\section{CONCLUDING REMARKS}

A preliminary analysis of bryozoan faunas in two separate basins, including beds from Paleocene to Eocene in age, indicates that the bryozoan fauna is a useful tool in chronostratigraphic discrimination, at least within these basins. A significant renewal of bryozoan fauna is apparent in both basins during the Middle Eocene. The exact chronostratigraphic correlation between these two basins is hard to establish. If the information available is absolutely reliable the faunal renewal in Europe is slightly older than that in North America.

\section{ACKNOWLEDGEMENTS}

To Prof. W. Berggren for the information supplied about the exact meaning of the North American Paleogene units. To Prof. E. Molina for his invitations to attend meetings

\begin{tabular}{|l|c|c|c|c|c|}
\hline & EX & FA & LA & BA & T \\
\hline CYCLOSTOMATA & 0 & 6 & 0 & 0 & 6 \\
\hline CHEILOST. ANASCA & 3 & 9 & 0 & 0 & 12 \\
\hline CHEIL. CRIBRIMORPHA & 0 & 0 & 0 & 0 & 0 \\
\hline CHEIL. ASCOPHORA & 4 & 12 & 0 & 0 & 16 \\
\hline
\end{tabular}

Table 10. Ypresian bryozoan species.

\begin{tabular}{|l|c|c|c|c|c|}
\hline & EX & FA & LA & BA & T \\
\hline CYCLOSTOMATA & 44 & 3 & 5 & 1 & 53 \\
\hline CHEILOST. ANASCA & 33 & 1 & 5 & 4 & 43 \\
\hline CHEIL. CRIBRIMORPHA & 4 & 1 & 0 & 0 & 5 \\
\hline CHEIL. ASCOPHORA & 41 & 0 & 11 & 1 & 53 \\
\hline
\end{tabular}

Table 11. Lutetian bryozoan species.

where one of the main goals was to discuss Paleogene chronostratigraphy. To Dr. P. D. Taylor, and also to Prof. E. Molina for the critical reading of the manuscript. To Robin Rycroft for improving my English text. This work was supported by the Spanish Project PB97 - 0882 - C03 -01.

\begin{tabular}{|l|c|c|c|c|c|}
\hline & EX & FA & LA & BA & T \\
\hline CYCLOSTOMATA & 0 & 0 & 4 & 0 & 4 \\
\hline CHEILOST. ANASCA & 6 & 0 & 5 & 0 & 11 \\
\hline CHEIL. CRIBRIMORPHA & 0 & 1 & 1 & 0 & 2 \\
\hline CHEIL. ASCOPHORA & 14 & 0 & 1 & 0 & 15 \\
\hline
\end{tabular}

Table 12. Bartonian bryozoan species.

\section{REFERENCES}

Annoscia, E. (Ed.).1968a. Proceedings of the First International Conference on Bryozoa. Atti della Società Italiana di Scienze Naturali e del Museo Civico di Storia Naturale di Milano, 108, 1-377.

Annoscia, E. 1968b. Paleontological and stratigraphical research carried out by AGIP Direzione Mineraria Paleontological Laboratory. In: Proceedings of the First International Conference on Bryozoa (Ed. E. Annoscia). Atti della Società Italiana di Scienze Naturali e del Museo Civico di Storia Naturale di Milano, 108, 25-27.

Bassler, R. S. 1953. Part G. Bryozoa. In: Treatise on Invertebrate Paleontology (Ed. R. C. Moore). Geological Society of America/University of Kansas Press. Lawrence, Kansas, G1-G253.

Boardman, R. S. 1968. Potential use of Paleozoic Bryozoa in subsurface exploration. In: Proceedings of the First International Conference on Bryozoa (Ed. E. Annoscia). Atti della Società Italiana di Scienze Naturali e del Museo Civico di Storia Naturale di Milano, 108, 28-30.

Braga, G. et Bignot, G. 1986. Les bryozoaires de la formation díage Paleocene (Danien probable) de Mont Aimé (Marne, Bassin Parisien). Geobios, 19, 279-293.

Buge, E. 1964. Les Bryozoaires du Paléogéne du Bassin de Paris (region parisienne et Cotentin): état actuel de nos conaissances et perspectives d'avenir. Mémoires $d u$ 
Bureau de Récherches Géologiques et Miniéres, 28 (2), 1049-1065.

Buge, E. 1972. Remarques sur les méthodes d'utilisation stratigraphique des Bryozoaires postpaléozoiques. Mémoires du Bureau de Récherches Géologiques et Miniéres, 77, 54-58.

Canu, F. and Bassler, R. S. 1920. North American Early Tertiary Bryozoa. United States National Museum Bulletin, 106, 1-879.

Cavelier, C. et Pomerol, Ch. 1976. Les rapports entre le Bartonien et le Priabonien. Incidence sur la position de la limite Éocéne moyen-Éocene supérieur. Comptes Rendus sommaires de la Société Géologique de France, 1976 (2), 49-51.

Gautier, Y. V. 1968. Bryozoa as microfossils which may be useful in oil research. In: Proceedings of the First International Conference on Bryozoa (Ed. E. Annoscia). Atti della Società Italiana di Scienze Naturali e del Museo Civico di Storia Naturale di Milano, 108, 31-36.

Jenkins, D. G. and Luterbacher, H. P. 1992. Paleogene stages and their boundaries (Introductory remarks). Neues Jahrbuch füir Geologie und Paläontologie. Abhandlungen, 186, 1-5.

Mancini, E. A. and Tew, B. H. 1991. Relationships of Paleogene stage and planktonic foraminiferal zone boundaries to lithostratigraphic and allostratigraphic contacts in the Eastern Gulf Coastal Plain. Journal of Foraminiferal Research, 21, 48-66.

Peniguel, G. 1959. Intêret stratigraphique et paléogeographique de Bryozoaires du Stampien des Landes de Gascogne. Université de Bordeaux (Thèse inédite). 1-221.

Reguant, S. 1993. Los briozoos como indicadores paleoambientales y como fauna de interés bioestratigráfico. Comunicaciones de las IX Jornadas de Paleontología, Málaga, 99-104.

Reguant, S. 1995. Bryozoa and Stratigraphy in Paleogene times through the study of Paleogene species from Europe. Revista Española de Paleontología, 10, 117128.

Reguant, S. 1999. Thirty one years (1968-1998) of Bryozoology: the I.B.A. International Conferences. Memorias de la Real Academia de Ciencias y Artes de Barcelona, n. ${ }^{\circ}$ 959, 58 (4), 139-153.

Sepkoski, J. J. 1982. A compendium of fossil marine families. Milwaukee Public Museum Contributions to Biology and Geology, 51, 1-125.

Taylor, P. D. 1993. Bryozoa. In: The Fossil Record 2 (Ed.M. J. Benton). Chapman \& Hall, London, 465-489.

Voigt, E. 1985. The Bryozoa of the Cretaceous-Tertiary boundary. In: Bryozoa: Ordovician to Recent (Eds. C. Nielsen and G. P. Larwood). Olsen and Olsen, Fredensborg, 329-342.

Manuscrito recibido: 17 de mayo, 1999 Manuscrito aceptado: 6 de septiembre, 1999 